\title{
A Physician Suffering from COVID-19 with Multiple Co-Morbidities Have Delayed Viral Clearance: A Case Report from Bangladesh
}

\author{
Md. Reaz Uddin Chowdhury ${ }^{1}$ [D, Kazi Shanzida Akter², Sahedul Islam Bhuiyan ${ }^{3}$, \\ Md. Khalilur Rahman Khabir ${ }^{4}$, Bimal Chandra Das' ${ }^{1}$, Muhammad Anwarul Kabir ${ }^{1}$ \\ ${ }^{1}$ Abdul Malek Ukil Medical College, Noakhali, Bangladesh \\ ${ }^{2}$ Dedicated COVID-19 Hospital-Trauma Center, Feni, Bangladesh \\ ${ }^{3}$ Brahmanbaria Medical College, Brahmanbaria, Bangladesh \\ ${ }^{4} 250$ Bed District Sadar Hospital, Feni, Bangladesh \\ Email: mail2drreaz@gmail.com
}

How to cite this paper: Chowdhury, Md.R.U., Akter, K.S., Bhuiyan, S.I., Khabir, Md.K.R., Das, B.C. and Kabir, M.A. (2020) A Physician Suffering from COVID-19 with Multiple Co-Morbidities Have Delayed Viral Clearance: A Case Report from Bangladesh. Advances in Infectious Diseases, 10, 94-100. https://doi.org/10.4236/aid.2020.103009

Received: June 25, 2020

Accepted: July 26, 2020

Published: July 29, 2020

Copyright $\odot 2020$ by author(s) and Scientific Research Publishing Inc. This work is licensed under the Creative Commons Attribution International License (CC BY 4.0).

http://creativecommons.org/licenses/by/4.0/

\begin{abstract}
Background: Novel corona virus (SARS-Coronavirus-2 SARS-CoV-2) which emerged in China has spread to multiple countries rapidly. Little information is known about delayed viral clearance in mild to moderate COVID-19 patients. As it is highly contagious, health care workers including physicians are high risk of being infected in hospital care. Case Report: A 37 years old Bangladeshi physician working in a paediatric unit of a medical college hospital with multiple co-morbidities, hypertension, diagnosed axial spondyloarthropathy (ankylosing spondylitis) taking disease modifying anti rheumatic drugsDMARDs (Salfasalazine) from 2016 till now, chronic persistent bronchial asthma on medication developed sore throat, increasing breathlessness and cough admitted to his own hospital on 22 April, 2020. He had a history of contact with a relapse nephrotic syndrome (glomerulonephritis) patient admitted with severe respiratory distress later confirmed as COVID-19 following RT PCR test on 14 April, 2020. After 3 days of contact with the patient, the physician also developed the symptoms mentioned above. The RT PCR test result of the physician came positive on 18 April, 2020. The physician primarily taken only azithromycin $500 \mathrm{mg}$ once daily along with other regular drugs. On 5,12 and 18 May, 2020, his sample was taken for re-test and came positive subsequently. After that he started Ivermectin $(0.15 \mathrm{mg} / \mathrm{kg})$ once daily for 3 days and doxycycline $100 \mathrm{mg} \mathrm{BD}$ for 7 days. He gave samples again on 27 and 29 May, 2020 which were came negative after 39 days. On full recovery he was discharged from hospital on day 40 . We choose the patient because presence of co-morbidities may be associated with delayed viral clearance and physicians with co-morbidities working in a hospital have high risk of being infected.
\end{abstract}




\section{Keywords}

Physician, Co-Morbidities, Viral Clearance, COVID-19, Case Report, Bangladesh

\section{Introduction}

The Current outbreak of novel corona virus (2019-nCoV) was first reported in China, on $31^{\text {st }}$ December 2019. Since then severe acute respiratory syndrome coronavirus 2 (SARS-CoV-2) has generated 9,271,341 confirm cases and 475,583 confirm death till June 23, 2020 [1]. COVID-19 has contributed enormous adverse impact globally. According to the latest reports, the clinical manifestations of COVID-19 are heterogenous [2] [3] [4] [5]. On admission 20-51\% of patients having at least one co-morbidity, with diabetes (10\% - 20\%), hypertension ( $10 \%$ - 15\%) and other cardiovascular and cerebrovascular disease (7\% - 40\%) being most common [3] [4] [6]. How over which underlying diseases that contribute the most to aggravate the conditions is still largely unknown. SARS-CoV-2 viral clearance is a gold standard for defining the recovery of COVID-19 infections [6]. One study showed that hypertension and diabetes delay the viral clearance in COVID-19 patients [6]. So patients of COVID-19 with multiple co-morbidities have more chance of developing complications as well as delayed viral clearance. We reported a case of 37 years old physician presented with COVID-19 with Hypertension, Bronchial asthma, Ankylosing spondylitis with delayed viral clearance though not developed any severe complications.

\section{Case Presentation}

The physician was a 37 years old man currently working in paediatric unit of a medical college hospital with multiple co-morbidities-hypertension, diagnosed axial spondyloarthropathy (ankylosing spondylitis) taking DMARDs (Salfasalazine $500 \mathrm{mg} 3$ times daily) from 2016 till now (see Table 1). On 14 April, 2020, when he was working in his ward got contact with a 12 years relapse nephrotic syndrome patient on high dose steroid and azathioprine admitted in the hospital with severe respiratory distress. The physician attended the patient several times during his treatment with proper personal protective equipments. After 3 days of his contact, the physician also developed sore throat, cough, fatigue, increasing breathlessness though his chronic asthma was remain controlled on medication and low grade fever $\left(100^{\circ} \mathrm{F}\right)$ but don't have diarrhoea, rhinorrhea or anosmia. On 18 April, 2020, he gave nasopharyngeal swab for RT PCR for Corona and it came positive. On 22 April, 2020, he got admitted in his own hospital. On admission vital signs were as follows: Blood pressure was $160 / 90 \mathrm{~mm}$ of $\mathrm{Hg}$ (he was on telmisartan $80 \mathrm{mg}$ and amlodipine $5 \mathrm{mg}$ antihypertensive drugs), Heart rate was $96 / \mathrm{min}$, Temperature was $100^{\circledR} \mathrm{F}$, Respiratory rate was 20 breath/min, Oxygen saturation was $97 \%$ on room air. He was advised to take azithromycin $500 \mathrm{mg}$ once daily, desloratidine $10 \mathrm{mg}$ once daily, paracetamol $500 \mathrm{mg} 3$ times daily along 
with his regular medication salfasalazine $500 \mathrm{mg}$ three times daily, increasing the dose of antihypertensive drugs and a anxiolytic, clonazepam $2 \mathrm{mg}$ at night daily. His base line investigations(22 April) reveals-Chest radiography normal, slightly raised Alanine aminotransferase (ALT), serum ferritin and moderately increased C-reactive protein $(\mathrm{C}-\mathrm{RP}$ ) and slightly raised D-dimer (see Table 2 ). High resolution

Table 1. Clinical and sociodemographic characteristics of the patient.

\begin{tabular}{|c|c|}
\hline $\begin{array}{l}\text { Sociodemographic and Clinical } \\
\text { Characteristics of the Patient }\end{array}$ & Parameter \\
\hline Age & 37 years \\
\hline Sex & Male \\
\hline Occupation & Clinical Physician \\
\hline Co-morbidity & Hypertension, Ankylosing Spondylitis \\
\hline $\begin{array}{l}\text { Date of Contact with a Positive } \\
\text { COVID- } 19 \text { patient }\end{array}$ & 14 April, 2020 \\
\hline $\begin{array}{l}\text { Date of } 1^{\text {st }} \text { Positive report of the } \\
\text { Physician on Nasopharyngeal swab. }\end{array}$ & 18 April, 2020 \\
\hline Date of Admission in the Hospital & 22 April, 2020 \\
\hline Clinical Presentation on Admission & $\begin{array}{l}\text { Sore throat, Cough, Fatigue, Shortness of Breath, Blood } \\
\text { pressure was } 160 / 90 \mathrm{~mm} \text { of } \mathrm{Hg} \text {, Respiratory rate was } 20 \\
\text { breath/min, Temperature was } 100^{\circledR} \mathrm{F} \text {, Oxygen saturation was } \\
97 \% \text { on room air. }\end{array}$ \\
\hline
\end{tabular}

Table 2. Base line investigations on 22 April, 2020.

\begin{tabular}{ll}
\hline Investigations (22 April, 2020) & Findings with reference range \\
\hline Hemoglobin (Hb) & $13.0 \mathrm{~g} / \mathrm{dl}$ (Adult male $13-18 \mathrm{gm} / \mathrm{dl})$ \\
Erythrocyte sedimentation rate (ESR) & $40 \mathrm{~mm}$ in $1^{\text {st }}$ hour $\left(0-10 \mathrm{~mm}\right.$ in $1^{\text {st }}$ hour) \\
Total White Blood Cell (WBC) count & $8700 / \mathrm{cmm}(4000-11,000 / \mathrm{cmm})$ \\
Neutrophils (Differentials) & $74 \%$ (Adult $40 \%-75 \%)$ \\
Lymphocytes (differential) & $10 \%$ (Adult $20 \%-50 \%)$ \\
Platelet count & $154,000 / \mathrm{cmm}(150,000-400,000 / \mathrm{cmm})$ \\
Random blood sugar & $6.7 \mathrm{mmol} / \mathrm{l}(<7.8 \mathrm{mmol} / \mathrm{l})$ \\
Serum Creatinine & $0.9 \mathrm{mg} / \mathrm{dl}($ Adult Male $0.7-1.2 \mathrm{mg} / \mathrm{dl})$ \\
Alanine Aminotransferase (ALT) & $67 \mathrm{U} / \mathrm{L}(\mathrm{Male}$ upto $45 \mathrm{U} / \mathrm{L}$ \\
C-Reactive Protein (C-RP) & $42 \mathrm{mg} / \mathrm{L}(<8 \mathrm{mg} / \mathrm{L})$ \\
Serum ferritin & $337 \mathrm{ng} / \mathrm{ml}(30-350 \mathrm{ng} / \mathrm{ml})$ \\
D-dimer & $0.67 \mathrm{microg} / \mathrm{ml}(\mathrm{less} \mathrm{than} 0.5 \mathrm{microg} / \mathrm{ml})$ \\
Chest X-ray (posterior -anterior view) & Within normal limit. \\
Sodium (Na $\left.{ }^{+}\right)$ & $137 \mathrm{mEq} / \mathrm{L}(135-145 \mathrm{mEq} / \mathrm{L})$ \\
Potassium (K+) & $4.4 \mathrm{mEq} / \mathrm{L}(3.5-5.3 \mathrm{mEq} / \mathrm{L})$ \\
Chloride (Cl) & $104 \mathrm{mEq} / \mathrm{L}(98-107 \mathrm{mEq} / \mathrm{L})$ \\
Electrocardiogram (ECG) & Within normal limit \\
\hline
\end{tabular}


computed tomography (HRCT) of chest and pro-calcitonin were not done. He was on the medication without any new symptoms or clinical deterioration till 12 May, 2020. On 5 May, he gave a nasopharyngeal swab for follow up test which was came positive again. He was remaining on the same medication till 12 May, when he was given another sample for RT-PCR which again came positive. After that his medication was reviewed as his symptoms cough, wheeze was not improved rather increasing respiratory distress $\left(\mathrm{SpO}_{2}\right.$ fluctuating to $88 \%$ to 93\%). After that on 13 May, 2020, some investigations reviewed including Chest X-ray which showed mild interstitial pneumonitis of both lung (Figure 1) but High resolution computed tomography(HR CT) of chest not done but D-dimer also came slightly raised. He was started ivermectin $(0.15 \mathrm{mg} / \mathrm{kg})$ for 3 days, nebulized salbutamol 4 hourly, bed side supplymental oxygen $4 \mathrm{~L}-6 \mathrm{~L} / \mathrm{min}$ by nasal canola, oral methylprednisolone $80 \mathrm{mg}$ daily and low molecular weight heparin (LMWH) enoxaparin $40 \mathrm{mg}$ subcutaneous twice daily, intravenous antibiotic (amoxicillin-clavulanic acid $1.2 \mathrm{gm}$ ) 3 times daily. During this time his condition gradually improved with sustain oxygen saturation above $97 \%$ on room air. On 18 May, 2020, he was given another nasopharyngeal swab which

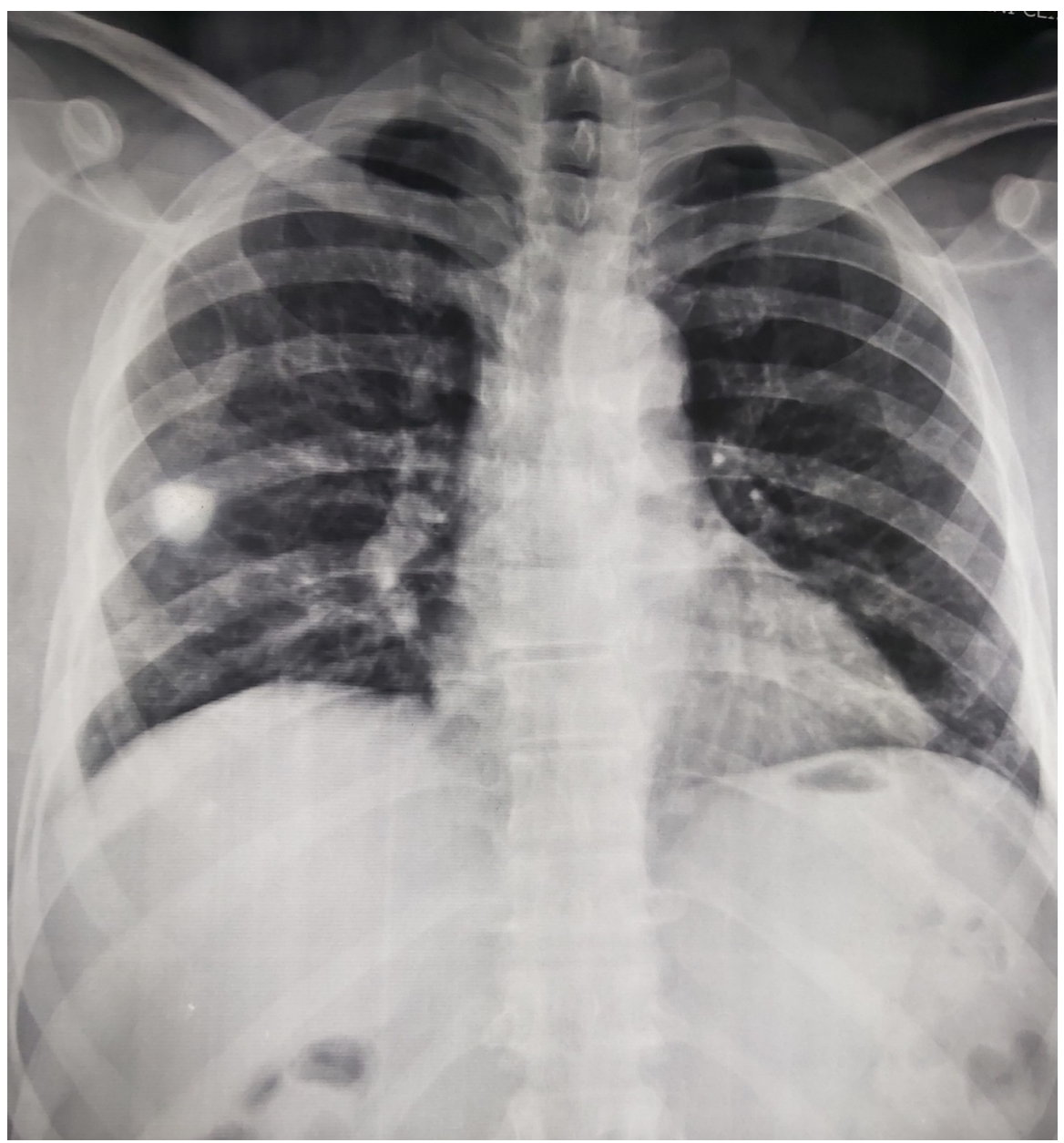

Figure 1. Follow up X-ray Chest Posterior-Anterior view on 13 May, 2020, showing mild interstitial Pneumonitis of both lungs. 
came positive. He continued the previous treatment without adding any new drug. On 27 and 29 May, 2020, he gave nasopharyngeal swab again which were came negative. Follow up X-ray Chest not done that time. On 28 May, 2020, he was discharged from hospital with anti-asthma medication, antihypertensive drug, sulfasalazine 500 three times daily along with oral Anticoagulants, rivaroxaban $20 \mathrm{mg}$ once daily for 1 month. We advised him for another 14 days home isolation and a follow up visit after 14 days in the outpatient department.

\section{Discussions}

The current COVID-19 pandemic is the third and most lethal outbreak of corona virus in the $21^{\text {st }}$ century in which the number of infections and mortality is suppressed those of both middle east respiratory syndrome and severe acute respiratory syndrome within a short period [7]. The spectrum of this disease ranges from mild to severe, even life threatening consequences. Some cases might progress to rapidly to acute respiratory distress syndrome [8] and/or multiple organ function failure [9]. Determining the viral dynamics and natural history of SAR-CoV-2 in different populations is crucial towards instituting public health policies and granting clearance for infected people [10]. One study showed that in young and healthy adult patients with COVID-19, the median duration of viral clearance is around 3 weeks [11]. This duration is higher than previous reports of a median between 9.5 and 20 days [12]. Another study showed that hypertension, diabetes and cardiovascular disease are associated with abnormal regulation of renin angiotensin system (RAS) and ACE 2 has key role involved in this process [13]. Other studies have shown that high expression of ACE 2 in the patient with hypertension, diabetes and cardiovascular disease might facilitate SARS-CoV-2 to enter the targeted cells in the respiratory system and prolong the viral clearance [14].Another study showed that patients with chronic arthritis treated with DMARDs do not seem to be at increased risk of respiratory and life threatening complications from SARS-CoV-2 compared with the general population [15]. In our case the patient showed viral clearance at 39 days after the date of positive result found on first oropharyngeal RT PCR test (see Table 3 ). This case highlights that COVID-19 with co-morbidities importantly hypertension and diabetes related with severe complications in elderly patients and

Table 3. RT PCR test result on Nasopharyngeal swab.

\begin{tabular}{cl}
\hline Sample from Nasopharyngeal swab: Date & Result \\
\hline 18 April, 2020 & Positive \\
5 May, 2020 & Positive \\
12 May, 2020 & Positive \\
18 May, 2020 & Positive \\
27 May, 2020 & Negative \\
29 May, 2020 & Negative
\end{tabular}


less severe in young patients and delayed viral clearance in all age groups. The later one was present in our case and taking DMARDs for long time does not associated with severity also found in our case which was also similar to above study.

\section{Conclusion}

COVID-19 patient presented with co-morbidity particularly with hypertension and diabetes should always have to give priority during treatment because they have more chance of developing severe disease particularly elderly patients. Those who are suffering from rheumatological disease taking DMARDs does not need to stop the drug as it is not associated with severe disease rather contribute to flare up the controlled disease. Though some study regarding this already published, we recommend more large scale trial still needed for a conclusive recommendation. Heath care worker (HCW) particularly physicians have high risk of being infected and multiple exposure to this virus may influence severity and delayed viral clearance. Further study is needed for a definite conclusion.

\section{Acknowledgements}

Informed consent was obtained from the patient for publication of this case report.

\section{Conflicts of Interest}

The authors declare no conflicts of interest regarding the publication of this paper.

\section{References}

[1] World Health Organisation (WHO) (2019) Corona Virus Disease 2019. (COVID19): Situation Report-84. WHO, Geneva.

[2] Huang, C., Wang, Y., Li, X., et al. (2020) Clinical Feature of Patients with 2019 Novel Corona Virus in Wuhan, China. The Lancet, 395, 497-506. https://doi.org/10.1016/S0140-6736(20)30183-5

[3] Chen, N., Zhou, M., Dong, X., et al. (2020) Epidemiological and Clinical Characteristic of 99 Cases of 2019 Novel Coronavirus Pneumonia in Wuhan, China: A Descriptive Study. The Lancet, 395, 507-513. https://doi.org/10.1016/S0140-6736(20)30211-7

[4] Wang, D., Hu, B., et al. (2020) Clinical Characteristics of 138 Hospitalized Patients with 2019 Novel Corona Virus Infected Pneumonia in Wuhan, China. JAMA, 323, 1061-1069. https://doi.org/10.1001/jama.2020.1585

[5] Kui, L., Fang, Y.Y., Deng, Y., et al. (2020) Clinical Characteristics of Novel Corona Virus Cases in Tertiary Hospitals in Hubei Province. Chinese Medical Journal, 133, 1025-1031.

[6] Chen, X.P., et al. (2020) Hypertension and Diabetes Delay the Viral Clearance in COVID19 Patients.

[7] Carlos, W.G., Dela Cruz, C.S., Cao, B., Pasnick, S. and Jamil, S. (2020) Novel Wuhan (2019-nCoV) Coronavirus. American Journal of Respiratory and Critical Care Medicine, 201, P7-P8. https://doi.org/10.1164/rccm.2014P7 
[8] Rothe Camilla, S.M., Peter, S., Gisela, B., et al. (2020) Transmission of 2019-nCoV Infection from an Asymptomatic Contact in Germany. The New England Journal of Medicine, 382, 970-971. https://doi.org/10.1056/NEJMc2001468

[9] Li, J., Niu, P.H., Yang, B., et al. (2020) Genomic Characterization and Epidemiology of 2019 Novel Coronavirus Implications for Virus Origins and Receptor Bindings. The Lancet, 395, 565-574. https://doi.org/10.1016/S0140-6736(20)30251-8

[10] Lo, L.L., Lio, C.F., Cheong, H.H., et al. (2020) Evaluation of SARS-CoV-2 RNA Shedding in Clinical Specimens and Clinical Characteristics of 10 Patients with COVID 19 in Macau. International Journal of Biological Sciences, 16, 1698-1707. https://doi.org/10.7150/ijbs.45357

[11] Liu, Y., Yan, L.M., Wan, L., et al. (2020) Viral Dynamics in Mild and Severe Cases of COVID19. The Lancet Infectious Diseases, 20, 656-657.

[12] Ling, Y., Yan, L.M., Wan, L., et al. (2020) Persistence and Clearance of Viral RNA in 2019 Novel Corona Virus Disease Rehabilitation Patients. Chinese Medical Journal, 133, 1039-1043.

[13] Fang, L.K. and Roth, G.M. (2020) Are Patients with Hypertension and Diabetes Mellitus at Increased Risk for COVID19 Infections? The Lancet Respiratory Medicine, 8, e21. https://doi.org/10.1016/S2213-2600(20)30116-8

[14] Li, X.C., Zhang, J. and Zhuo, J.L. (2017) The Vasoprotective Axes of the RenninAngiotensin System: Physiological Relevance and Therapeutic Implications in Cardiovascular, Hypertensive and Kidney Disease. Pharmacological Research, 125, 21-38. https://doi.org/10.1016/j.phrs.2017.06.005

[15] D'Antiga, L. (2020) Coronaviruses and Immunosuppressed Patients. The Facts during the Third Epidemic. Liver Transplantation, 26, 832-834.

https://doi.org/10.1002/lt.25756

\author{
Abbreviations \\ COVID-19, Corona virus disease 2019, \\ RT-PCR, Reverse transcription Polymerase chain reaction, \\ DMARDs, Disease Modifying Anti-rheumatic drugs.
}

